\title{
China's Death Penalty Reform: Developments or Beyond?
}

\author{
$\mathrm{Na}$ Jiang* \\ Associate Professor of College for Criminal Law Science, Beijing Normal University, Beijing, P.R. China
}

*Corresponding author: Na Jiang, Associate Professor of College for Criminal Law Science, Beijing Normal University, china, Tel: 01058802774, 13261991907; E-mail: na.jiang@bnu.edu.cn

Received date: May 06, 2014, Accepted date: September 05, 2014, Published date: September 09, 2014

Copyright: (c) $2014 \mathrm{Na}$ Jiang. This is an open-access article distributed under the terms of the Creative Commons Attribution License, which permits unrestricted use, distribution, and reproduction in any medium, provided the original author and source are credited.

\begin{abstract}
In late August 2010, a new draft amendment to the Criminal Law of the PRC, proposing to reduce the number of crimes punishable by death for less executions and better human rights, was submitted to the Standing Committee of the National People's Congress. Even if this amendment becomes effective, the latest development is just a new step closer to abolition of the death penalty and not a landmark at all, without properly filling in the gap between legislation and policy. The Chinese legislation will still deviate from its policy on the death penalty and some ICCPR provisions to a certain degree.
\end{abstract}

Keywords: Latest developments; Death penalty reform; Draft amendment; Chinese legislation

\section{Introduction}

China has the world's highest number of executions in total numbers, but no time-frame is available at present for its gradual abolition of the death penalty. As China takes cautious steps towards ratification of the International Covenant on Civil and Political Rights (ICCPR), reform on the number of crimes attracting capital punishment has been actively discussed, apart from other issues relating to such crimes. There have been, over recent months, the latest developments in both attitudes toward, and implementation of, death penalty reform in China. Most notably, a new draft amendment to the Criminal Law of the PRC (1997CL), proposing to reduce the number of crimes punishable by death for less executions and better human rights, was submitted to the Standing Committee of the National People's Congress (NPC) for reading from late August, 2010 This paper will explore more details of the latest developments in China's death penalty reforms, in an attempt to assess its relevant policy and compliance with international human rights law.

As China's top legislature, the NPC Standing Committee began its first reading of the eighth amendment to the 1997CL in draft, at the 16th meeting from 23 August 2010. This draft amendment cannot be adopted or come into effect until being read two or three times in most cases. In terms of content, however, the relevant proposals contained in the draft revision would further limit use of capital punishment from various aspects and implement the policy of tempering justice with mercy in China's practice.

Specifically, the draft amendment proposes to eliminate the use of capital punishment for 13 economic-related and non-violent offences that are less or hardly practiced, from the 1997CL. The 13 crimes relate to three chapters in the 'Specific Provisions' of the Criminal Law, namely, Chapter Three concerning the 'Crimes of Undermining the Socialist Economic Order', Chapter Five relating to the 'Crimes of Property Violation' and Chapter Six on the 'Crimes of Obstructing the Administration of Public Order'. The Chapter Three includes 9 out of 13 crimes, namely, the crime of smuggling cultural relics (Article
151(2)), crime of smuggling precious metals (Article 151(2)), crime of smuggling precious and rare species of animals and the products thereof (Article 151(2)), crime of smuggling ordinary goods and articles (Article 153), crime of financial bills fraud (Article 194(1)), crime of monetary documents fraud (Article 194(2)), crime of credit fraud (Article 195), crime of falsely issuing exclusive value-added tax invoices, defrauding export tax refunds or offsetting taxes invoices (Article 205), and the crime of forging or selling forged exclusive value-added tax invoices (Article 206). Chapter Five only encompasses one crime, that is, the crime of theft (Article 264). Other three crimes, in the Chapter Six, cover the crime of teaching crime-committing methods (Article 295), crime of robbing ancient cultural ruins and ancient tomb burial objects (Article 328(1)), and the crime of robbing ancient human fossils and ancient vertebrate fossils (Article 328(2)). The above 13 crimes constitute almost 20 percent of the current 68 crimes punishable by death in total, probably meaning fewer crimes subject to the death penalty in Chinese legislation. More precisely, with a drop of 19.1 percent, 55 crimes would remain punishable by death in the 1997CL.

Moreover, the draft revision allows for leniency to offenders above 75 years old, by stating that the death penalty is not applicable to persons who reached the age of 75 at the time a capital crime is committed [1]. Different from the above reduction of crimes punishable by death in number, exemption of certain categories of offenders from the currently applicable scope is another practical approach to restricting the use of capital punishment. In detail, both those below 18 years old at the time a capital crime was committed and such women that pregnant at the time of hearing, are exempt from the applicable scope of capital punishment at present. But according to the draft amendment, the elder who reached the age of 75 and commits a crime will be given a mitigated punishment, instead of capital punishment. In other words, it is very likely for elder offenders above 75 years old to become another group of persons excluded from imposition of the death penalty. Similar to cutting back the number of capital crimes, such exclusion also benefits less death sentences or executions to promote China's human rights protection. 


\section{Background}

With the draft amendment being submitted to the NPC Standing Committee, the potential change on China' death penalty reform is under way and thus triggers various discussions. Among them, objective and rational commentaries primarily consider such background factors as follows.

\section{Chinese policy on the death penalty}

In contemporary China, the present death penalty policy is 'to kill less' and cautiously [2], 'those who do not have to be killed should not be sentenced to death', which reflects the criminal policy of tempering justice with mercy. This Chinese policy seems to essentially adopt strict limits on the use of the death [3] penalty. For years, however, external bodies have strongly criticised that: 'There is a huge gap between policy and practice with regard to the death penalty in China [4].' Since Chinese official arguments appear to be more general and political than pertinent, it is difficult to find a series of diametrically opposed disputes in the White Papers of the Chinese Government.

Generally speaking, the death penalty policy is the significant guideline for the establishment and application of the death penalty in China [5]. Owing to the direct effect of this policy on Chinese legal practices in general, it is reasonable to explore related legislation in China in an attempt to demonstrate and assess this policy. Legal practices also tend to directly describe the situation whether or not China faithfully performs its international human rights obligations.

\section{The relevant criminal legislation}

Under Chinese legal systems, the substantive criminal legislation is a basic branch of laws separate from the procedural one. The 1997CL [6] is the primary legal source of substantive laws on the death penalty, which specifies relevant crimes and punishments. This will be analysed in detail from the perspectives of exclusive categories in 'General Provisions' and capital crimes 'Specific Provisions'.

As 1997CL Article 49 indicated, persons who have not attained the age of 18 at the time the crime was committed or 'women who are pregnant at the time of trial' are two categories of persons excluded from the application of capital punishment. The exemption of the first group of persons means that 'Sentence of death shall not be imposed for crimes committed by persons below eighteen years of age'. Nonetheless, the second group of persons is 'women who are pregnant', only at the time of trial' and not all stages of proceedings, by 1997CL Article 49. The 'trial', basically, refers to the periods of the hearing and sentence in court, precluding the stage of pretrial detention and subsequent phases before execution. The scope of 'women who are pregnant at the time of trial' also contains such pregnant women that were accused of capital offences in court after spontaneous abortion during detention, as the Reply of the Supreme People's Court on Whether to Apply Capital Punishment to Pregnant Woman Normally Aborted during Detention in Trial [7] interpreted.

In 'Specific Provisions', nine out of ten chapters of the 1997CL have provisions relating to capital punishment, except for 'Crimes of Dereliction of Duty', with 68 capital charges in total. The number is respectively 7 in Chapter One, 14 in Chapter Two, 16 in Chapter Three, 5 in Chapter Four, 2 in Chapter Five, 8 in Chapter Six, 2 in Chapter Seven, 2 in Chapter Eight, 12 in Chapter Ten. This broad applicable scope seems to go beyond 'most serious crimes' and run against China's policy of strict limits on capital punishment. It might be evidenced from the following classification of violent and nonviolent crimes.

The death penalty appears to apply to more non-violent than violent crimes in the 1997CL. It tries to distinguish between violent and non-violent crimes according to whether they are committed in violent ways and directly endanger personal security [8]. There are 358 non-violent crimes and 63 violent crimes, among a total of 421[9]. However, the death penalty as the legal maximum penalty for nonviolent crimes is applied to 44 crimes in 8 major different kinds of crimes. These crimes account for approximately $65 \%$ of all capital charges and $12 \%$ of total non-violent crimes [10]. This appears not to indicate that China strictly limits the applicable scope of capital punishment.

\section{Comparison with ICCPR provisions}

The ICCPR involves various international obligations, among which Article 6 is the right to life provision to expressly refrain from arbitrary deprivation of life and authorise the death penalty in a restrictive manner. With a series of restrictions on its use, this penalty must be applied as 'a quite exceptional measure' [11]. China has not yet become a party to the ICCPR [12], but is still exploring what effect acceptance of the ICCPR would have on its domestic practice. It is necessary for China to draw a comparison between its current legislation and ICCPR provisions.

As an important substantive limitation, ICCPR Article 6(2) declares that the death penalty is imposed only for the 'most serious crimes'. It authorized the use of the death penalty within this range in restrictive terms. Similarly, 1997CL Article 48 also explicitly states the limits on the applicable scope of the death penalty in principle, namely in the context of 'extremely serious crimes'. This generally refers to the crimes with extremely odious circumstances, seriously endangering the essential interests of the State, society and people, according to authoritative textbooks like the Chinese Criminal Law [13]. Thus, only the criminals who have severely endangered the interests of citizens, society and the nation may be sentenced to death. Literally, 'extremely serious crimes' in 1997CL Article 48 and 'most serious crimes' in ICCPR Article 6(2) have the same meaning and coverage. In this sense, the general applicable scope of capital punishment in the Chinese legislation appears to conform to the relevant requirement of the ICCPR.

Concerning limitation in imposition, ICCPR Article 6(5) stipulates that 'sentence of death shall not be imposed for crimes committed by persons below eighteen years of age'. This contains a substantive limitation to the death penalty on young person's less than 18 years old. In this context, the age at the time of committing crimes appears to be an essential factor and the 'eighteen years of age' is an age limit. Considering 'crimes committed', offenders shall not be sentenced to death for 'crimes committed' below the age of 18, even if being convicted at the time they are beyond the age of 18 years. On the contrary, they are eligible for the imposition of the death penalty if older than 18 at the time of committing crimes. By comparison, 1997CL Article 49 is just required by Article 6(5). On limitation in execution, ICCPR Article 6(5) also requires the State not to carry out the death penalty on pregnant women. This explicitly prohibits the death penalty from being executed on such persons. But 1997CL does not appear to exempt all pregnant women from the application of capital punishment. Hence, there is an obvious difference between the above Chinese legislation and ICCPR Article 6(5). 
Page 3 of 5

\section{Comments}

If the draft amendment becomes law, it would be the first time that the number of crimes subject to the death penalty has been reduced and those reaching the age of 75 have been exempted from death sentences, since the PRC enacted its criminal law in 1979. Such latest developments are likely to constitute a major improvement towards China's progressive abolition of the death penalty, in preparation for its earlier ratification of the ICCPR. The relevant comments will be further developed from both positive and negative aspects.

\section{Positive comments}

Positively, the latest developments on death penalty reform will be a new step and major move by China closer to abolition of the death penalty, after the Supreme People's Court took back the review and approval of all death sentences in July 2007. This partly results from largely reducing the number of capital crimes in the draft revision to the 1997CL, first proposed in recent 30 years and without substantive changes of the total before that.

In comparison with 38 capital charges in both the 1979CL and Provisional Regulations on Punishing Military Personnel for Violation of Duty, adopted in 1981, the 1997CL has increased the number by 30 . With the campaign of 'Strike Hard', 12 separate criminal laws were successively promulgated and 33 more capital charges were added from 1982 to 1995 . The total number rose to 71 , excluding overlapping crimes, which was revised to 68 in the 1997CL. This appears to reduce the number of capital charges by 3 , while at the same time increasing the scope of crimes punishable by death. In effect, the 1997CL has abolished three such crimes [14] yet increased several ones [15] exclusive of those that have been disassembled.

Specifically, the number of capital charges in 1997CL Chapter One has decreased by 6 although the scope of the offences remains the same [16]. The charges of two crimes, namely illegal speculation and profiteering, and hooliganism, have been removed and the crimes reclassified as several diverse charges. They still carry the death penalty in their most severe form. The crimes of manufacturing or selling fake medicine and of manufacturing or selling toxic or harmful foodstuff retain the death penalty. The crime of affray, however, only receives it under the circumstances of causing personal death or injury, as a crime of injury or homicide, according to the principle of punishing the implicated offence [17] in 1997CL Article 292. Moreover, two capital charges of the crime of stealing valuable cultural relics and of abducting and trafficking in persons have been abolished and the crimes incorporated into a new charge and another broad one [18], both of which retain the death penalty. The crime of falsely making out specialized value-added-tax receipts and crime of falsely making out other receipts to obtain tax refunds or non-payment are also combined into one capital charge.

After the signing of the ICCPR in 1998, no specific criminal laws, judicial interpretations or amendments to the 1997CL increase the scope of the death penalty in China. There are two points worthy of note. First, Amendment III to the 1997CL was reported to prescribe the application of capital punishment to the crimes of terrorism [19], which misunderstood its real meanings. Actually, the act of terrorism shall be punishable by death as one of the crimes that endanger public security and not those of terrorist organizations. The use of capital punishment is unlikely to increase the extent of this penalty. Second, 'Guangdong bag snatchers may face the death penalty' [20], which never brings any increase in its use. The acts of drive-by thieves with violence constitute the crime of robbery, which appears to fall within the original extent of capital punishment.

Moreover, there is no decrease in the applicable scope of capital punishment after 1998. The basically unchanged scope seems not to directly breach the relevant provisions in the ICCPR. But the extensive use of capital punishment might go against China's official death penalty policy and give a broad coverage to 'the most serious crimes' provided in ICCPR Article 6(2).

\section{Negative comments}

Negatively, the latest developments tend not to be a landmark on China's death penalty reform as expected. China still has a long way to go in its strict limit on use of capital punishment as required by the ICCPR, not to mention towards eventual abolition of the death penalty. This could be demonstrated from several primary aspects.

Even with the above draft amendment, both the broad applicable scope of the death penalty in principle and non-violent crimes subject to the death penalty, still exist in the 1997CL as major obstacles to reform progress. This relates to misunderstanding or abuse of 'the most serious crimes', as stipulated in ICCPR Article 6(2). Since the definitions on serious crimes vary from one country to another, the vague formulation has been adopted with varying interpretations. This seems to lead to the conclusion that 'States are completely free to qualify a crime' as 'serious' or 'most serious'[21], but it has been universally accepted to exclude petty offences from the scope of its use. Without an explicit definition in any international instruments, there are various explanations on this concept in the UN practice. Nonetheless, the Human Rights Committee expressed the reading of the 'most serious crimes' so restrictively as to consider the death penalty as 'a quite exceptional measure'[22]. The Economic and Social Council confirmed that the scope of this term 'should not go beyond intentional crimes, with lethal or other extremely grave consequences' in the Safeguards Guaranteeing Protection of the Rights of Those Facing the Death Penalty [23]. Any intentional crimes which infringe life appear to be 'most serious crimes' and apply the death penalty [24]. The 'other extremely grave consequences' appear to indicate that other circumstances, e.g., circulation of 'secret information to an enemy in wartime', may lead to large-scale loss of life [25]. Moreover, the Special Rapporteur on Extrajudicial, Summary or Arbitrary Executions considers that 'the death penalty should be eliminated for crimes such as economic crimes and drug-related offences' [26], apart from 'other so-called victimless offences, or activities of a religious or political nature', or 'actions primarily related to prevailing moral values'[27].

Additionally, one of the legislative patterns of the death penalty is the 'absolute punishment of the death penalty' [28] for certain crimes [29]. This takes the death penalty as the sole and mandatory punishment, regardless of the diverse circumstances of such crimes. Other lighter penalties would not be applied to replace with capital punishment at the discretion of judges. This leaves no possibility of limiting and reducing the imposition of capital punishment for these crimes under any circumstances. Even if these crimes could be explained as 'the most serious crimes' punishable by death, the legislative pattern appears not to justify this case 'as a quite exceptional measure'. 
Page 4 of 5

\section{Conclusion}

Even if the eighth amendment to the 1997CL in draft becomes effective, the latest development is just a new step closer to abolition of the death penalty and not a landmark at all. In general, the Chinese legislation will still deviate from its policy on the death penalty and some ICCPR provisions to a certain degree.

At the substantive level, most of legal provisions concerning capital punishment in China appear to conform to the ICCPR, except for the limited scope of pregnant women excluded from execution of capital punishment. Although the general applicable scope-'extremely serious crimes' seems consistent with ICCPR Article 6(2), it extensively covers the crimes of endangering the State Security, of endangering public security; of undermining the Socialist economic order, of infringing upon the rights of the person and the democratic rights of citizens, of property violation, of obstructing the administration of public order, of endangering interests of national defence and of embezzlement and bribery; and crimes contrary to duties committed by servicemen. This appears to go against the death penalty policy and requirement of the ICCPR. Not all pregnant women, but only those 'at the trial' are excluded from capital punishment, which is different from pregnant women exempted from only the execution of capital punishment in ICCPR Article 6(5) and the relevant customary obligations. Clearly, the draft amendment cannot properly fill in the above gap in legislation.

\section{Reference}

1. China Tempers Justice with Mercy by Amending Criminal Law, Xinhua Net.

2. Mao Zedong (1991) Mao Zedong Selected Works [Mao Zedong Xuanji]. People's Publishing House 5: 1271.

3. Ibid., pp:40.

4. (2005) China: Horrific New Year. AI:ASA 17/007/2005.

5. Zhao Bingzhi (2004) Gradual Abrogation of the Death Penalty Regarding the Non-Violent Crimes from the perspective of Chinese Death Penalty Policy. In Zhao Bingzhi, edn, The Road of Abolition of the Death Penalty in China-Regarding the Abolition of the Non-Violent Crimes at the Present Stage. Press of Chinese People's Public Security University of China 18.

6. The 1979CL was revised on 14th March 1997 that is called the 1997CL. Subsequently, Amendments I-VII to the 1997CL were promulgated by the NPC Standing Committee, respectively on 25th December 1999, 31st August 2001, 29th December 2001, 28th December 2002, 28th February 2005, 29th June 2006 and 28th February 2009.

7. The SPC () Reply of the Supreme People's Court on Whether to Apply the Death Penalty to Pregnant Woman Normally Aborted during Detention in Trial. [Zuigao Renmin Fayuan Guanyu Dui Huaiyun Funv Zai Jiya Qijian Ziran Liuchan Shenpan Shi Shifou Keyi Shiyong Sixing Wenti De Pifu], from China.

8. Huang Jingping, Shilei (2004) Briefly Analyzing Non-Violent Crimes and Legislation of Death Penalty on Chinese Criminal Law. In Zhao Bingzhi, ed., The Road of Abolition of the Death Penalty in Chin-Regarding the Abolition of the Non-Violent Crimes at the Present Stage, Press of Chinese People's Public Security University of China 8.

9. (2004) China: Move to Reduce Executions? AI:ASA 17/053/2004.

10. General Comment No. 06: The right to life (Article 6): 30/04/82.
11. UN Doc. A/RES/2200A (XXI), 999/UNTS/171.

12. Qu Xinqiu (2002) The Penal Policy Analyzed from Power [Xingshi Zhengce De Quanli Fenxi]. Publishing House of the China University of Political Science and Law 49.

13. Crime of organising or using superstitious sects engage in counterrevolutionary activities; crime of carrying on counterrevolutionary activities through feudal superstition; crime of sabotaging weaponry.

14. 1997CL Articles 125(2), 369(1), 370(1), 422 and 439.

15. The original crime of secret service was merged into crime of espionage, the previous crime of instigating rebellion and crime of armed mass rebellion were combined into the crime of armed rebellion; crime of organizing a mass prison raid and crime of organizing a jailbreak were brought into crimes of disrupting the order of social administration; original crime of counterrevolutionary sabotage, crime of counterrevolutionary murder and crime of counterrevolutionary homicide or injury apply punishments of crime against public security, crime of intentional murder and injury with the abolition of their charges.

16. It is Qianlian Fan in Chinese, which is defined as a circumstance where criminals commit offences whose purpose constitutes one crime and criminal means or results does another crime.

17. They are the crime of smuggling valuable cultural relics and of abducting and trafficking in women and children.

18. Wu Liming, Fu Shuangqi (2001) Chinese Criminal Law Adds the Anti-Terrorism Content, and Terrorist Crimes Can be Sentenced to Death. [Zhongguo Xingfa Jiaru Fankong Neirong Kongbu Fanzui Kebei Panchu Sixing], from Xinhua Agency [Xinhua She].

19. (2006) China: Guangdong Bag Snatchers May Face Death Penalty. AI Index: ASA.

20. Sapienza R (1985) International Legal standards on Capital Punishment. In B.G. Ramcharan eds., The Right to Life in International Law, Dordrecht: Martinus Nijhoff Publishers.

21. General Comment No. 06: The right to life (Article 6): 30/04/82.

22. (1984) Safeguards Guaranteeing Protection of the Rights of Those Facing the Death Penalty', UN Doc.E/Res/ 1984/50(25/05/1984).

23. Consideration of Reports Submitted by States Parties under Article 40 of the Covenant: Comments of the Human Rights Committee', CCPR/C/79/Add.1(Algeria25/09/92)[5].

24. Rodley SN (1989) Human Rights and Humanitarian Intervention: The Case Law of the World Court.

25. (1998) Report of the Special Rapporteur on Extrajudicial, Summary or Arbitrary Executions', UN Doc.E/CN. 4/1998/68[94].

26. Ibid.,39[63]

27. Hu Changlong (2003) Research on Issues of Procedures for Capital Cases [sixing anjian chengxu wenti yanjiu]. Publishing House of the Chinese People's Public Security University 177.

28. They are the 5 crimes of the Crimes of Endangering National Security, including treason, the crime of splitting the country, crime of defecting to the enemy and turning traitor, crime of stealing, secretly gathering, purchasing, or illegally providing State secrets or intelligence for an organisation, institution, or personnel outside the country, the crime of supporting enemy; the crimes of the Graft and Bribery, and the crime of fabricating 
Citation: Jiang N (2014) China's Death Penalty Reform: Developments or Beyond?. Intel Prop Rights 2: 125. doi:10.4172/2375-4516.1000125

Page 5 of 5

rumors to mislead people on the Crimes of Violation of Duty by 29. General Comment No. 06: The right to life (Article 6): $30 / 04 / 82$. Military Personnel. 